\title{
Macronutrient Fertilization on the Yield Components and Nutrition of Lima Bean
}

\author{
Flávia L. A. Santiago ${ }^{1}$, Franklin E. M. Santiago ${ }^{2}$, Adênio L. Aguiar Júnior ${ }^{1}$, Júlio César A. Nóbrega ${ }^{3}$, \\ Bruno O. Dias ${ }^{4} \&$ Rafaela S. A. Nóbrega ${ }^{3}$ \\ ${ }^{1}$ Federal University of Lavras, Minas Gerais, Brazil \\ ${ }^{2}$ Federal Institute of Piauí, Piauí, PI, Brazil \\ ${ }^{3}$ Federal University of Recôncavo of Bahia, Bahia, BA, Brazil \\ ${ }^{4}$ Federal University of Paraiba, Paraíba, PB, Brazil \\ Correspondence: Flávia L. A. Santiago, Science Soil Department, Federal University of Lavras, Minas Gerais, \\ Brazil. E-mail: flavialouzeiro20@gmail.com
}

\author{
Received: January 7, $2019 \quad$ Accepted: February 10, $2019 \quad$ Online Published: April 15, 2019 \\ doi:10.5539/jas.v11n5p395 URL: https://doi.org/10.5539/jas.v11n5p395
}

\begin{abstract}
Lima bean stands out in the agricultural sector as a source of income for small and medium farmers, being an important protein source for the population. However, there few studies related to the adequate management of fertilization that subsidize the maximization of crop production. In this context, the objective of this research was to evaluate the effect of macronutrient doses on the yield components and nutritional status of lima bean. The treatments were chosed based on the statistical arrangement of the Baconian method. Six nutrients (nitrogen, phosphorus, potassium, calcium, magnesium and sulfur) were applied in three different doses along with two additional treatments, one with reference doses and the other with no addition of nutrients, totaling 20 treatments that were arranged in a completely randomized design with four replications. The pod length, pod number per plant, pod weight, number of grains per pod, number of grains per plant, grain weight per plant and macronutrient leaf contents were evaluated. The addition of macronutrients leads to increases in yield components and nutritional status of lima bean s when cultivated in Entisol Quartzipsamment. The doses of macronutrients that promote higher productive yield and adequately supply the nutritional needs of lima beans are: $25 \mathrm{mg} \mathrm{N} \mathrm{dm}^{-3} ; 157 \mathrm{mg} \mathrm{P}_{2} \mathrm{O}_{5}$ $\mathrm{dm}^{-3} ; 90 \mathrm{mg} \mathrm{K}_{2} \mathrm{O} \mathrm{dm}{ }^{-3} ; 1.27 \mathrm{cmol}_{\mathrm{c}} \mathrm{Ca} \mathrm{dm}^{-3} ; 0.50 \mathrm{cmol}_{\mathrm{c}} \mathrm{Mg} \mathrm{dm}^{-3}$ and $30 \mathrm{mg} \mathrm{S} \mathrm{dm}^{-3}$.
\end{abstract}

Keywords: mineral fertilization, nutritional status, productivity, Phaseolus lunatus (L)

\section{Introduction}

Lima bean (Phaseolus lunatus L.) is one of the five cultivated species of the genus Phaseolus ssp. and the second most important bean, after common bean (Phaseolus vulgaris) (Bitocchi et al., 2017). In Brazil, lima bean stand out in the agricultural sector as a source of income for small and medium farmers and for being an important protein source for the population.

In addition, their grains have a high content of lectin, which is a protein responsible for important biological functions in human health, such as antioxidants, antitumor and gastroprotective (Lacerda et al., 2017). Furthermore, besides those benefits, lima bean is widely used in animal nutrition, green manuring and as a cover crop for soil protection (Silva et al., 2017).

The Brazilian Northeast region is the most prominent region in lima bean production. However, fluctuations in the final yield of this crop have been noticed in recent years. In 2009, 20 tons of grain were produced, which was considered the highest production in the last ten years, in an area of 45,431 ha. The largest producers were the states of Paraíba, Rio Grande do Norte, Ceará, Piauí and Sergipe. In recent years, there has been a drastic reduction in production, with an average harvest of only 6 thousand tons of grains and an average yield of $288 \mathrm{~kg} \mathrm{ha}^{-1}$ (Instituto Brasileiro de Geografia e Estatística, 2015).

The factors responsible for the oscillations and low productivity of lima bean in the largest producing region of Brazil, are the prolonged droughts occurred in the last years, the scarcity of information on the cultivation of this species, fertilization management and the nutritional requirements of the crop. For example, in the state of Piauí, 
which occupies the $4^{\text {th }}$ place in the production ranking with $616 \mathrm{t} \mathrm{year}^{-1}$, there are no studies related to fertilization management of this crop in typical soils of the region, which contributes to the low productivity in the State with an average of $347 \mathrm{~kg} \mathrm{ha}^{-1}$ (Instituto Brasileiro de Geografia e Estatística, 2014).

Considering the lack of studies related to the nutritional management of lima bean and the need to maximize their production, the objective of this research was to evaluate the effect of macronutrient doses on the production components and nutritional status of this plant.

\section{Material and Methods}

The study was conducted under the greenhouse at the Federal University of Piauí, Campus Bom Jesus, from February to June of 2014. The monthly average temperature and relative humidity of the air inside of the greenhouse during the experimental period are shown in Figure 1.

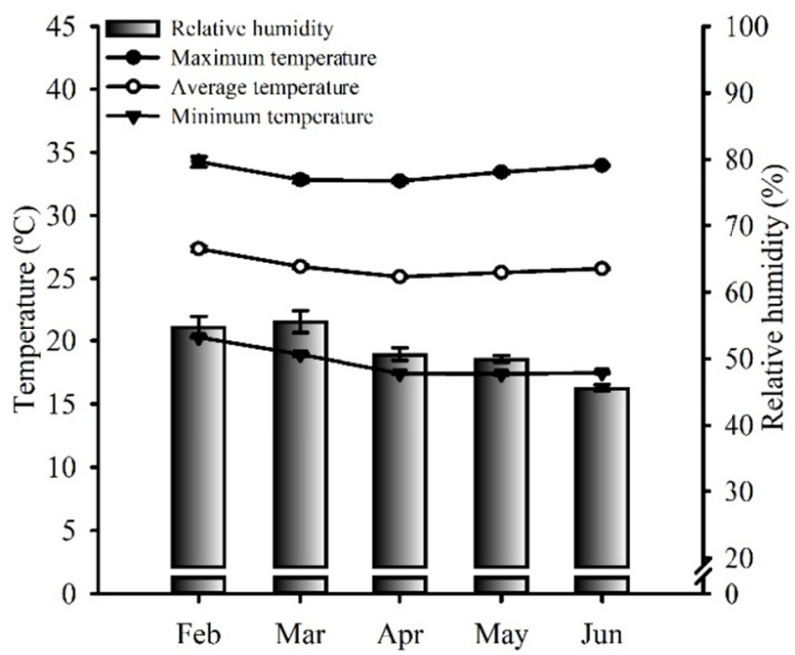

Figure 1. Temperature and relative humidity inside the greenhouse during the experiment period, February at June of 2014

The soil used in the study was a Entisol Quartzipsamment (Empresa Brasileira de Pesquisa Agropecuária, 2013), collected from the 0-0.20 m depth layer, in a native forest area. After sampling, soils were air dried and passed through a 4.0-mm sieve. The chemical characterization of the soil was performed according to the methodology described by Embrapa (2009) and presented the following values: $\mathrm{pH}$ in $\mathrm{H}_{2} \mathrm{O}=4.6 ; \mathrm{OM}=0.4 \mathrm{~g} \mathrm{~kg}^{-1}$; $\mathrm{P}$ (Mehlich-1) $=1.7 \mathrm{mg} \mathrm{dm}^{-3} ; \mathrm{K}^{+}=27 \mathrm{mg} \mathrm{dm}{ }^{-3} ; \mathrm{Ca}^{2+}=0.8 \mathrm{cmol}_{\mathrm{c}} \mathrm{dm}^{-3} ; \mathrm{Mg}^{2+}=0.5 \mathrm{cmol}_{\mathrm{c}} \mathrm{dm}^{-3} ; \mathrm{Al}^{3+}=0.2 \mathrm{cmol}_{\mathrm{c}} \mathrm{dm}^{-3} ; \mathrm{H}+\mathrm{Al}=6.1$ $\mathrm{cmol}_{\mathrm{c}} \mathrm{dm}^{-3} ; \mathrm{SB}=1.3 \mathrm{cmol}_{\mathrm{c}} \mathrm{dm}^{-3} ; \mathrm{t}=1.5 \mathrm{cmol}_{\mathrm{c}} \mathrm{dm}^{-3} ; \mathrm{T}=7.4 \mathrm{cmol}_{\mathrm{c}} \mathrm{dm}^{-3} ; \mathrm{m}=13.3 \% ; \mathrm{V}=17.5 \%$.

Treatments were arranged according to the Baconian method (Turrent, 1979), in which one of the nutrients is supplied in varying amounts, while the others are kept at reference levels (Table 1). Six nutrients (nitrogen, phosphorus, potassium, calcium, magnesium and sulfur) were evaluated in three different doses. Two additional treatments were used; one with all reference doses and another with no addition of nutrients, totaling 20 treatments arranged in a completely randomized design with four replicates.

Each experimental unit was composed of $5 \mathrm{dm}^{3}$ of soil conditioned in plastic pots with the same capacity. Subsequently, doses of $\mathrm{CaCO}_{3}$ and $\mathrm{MgCl}_{2}$ were added to the soil according to amounts defined for each treatment (Table 1). The system was kept incubated for a period of 30 days with humidity at $70 \%$ of field capacity.

After the incubation period, the other nutrients were added according to the amounts defined in Table 1. Phosphorus was applied in the form of single superphosphate at the time of seedling. Potassium and sulfur doses were applied in the base fertilization and parceled at 30 and 60 days after sowing, by using potassium chloride and magnesium sulphate, respectively. Nitrogen was applied at 30 and 60 days after sowing, using urea as source. In the same period, a solution of micronutrients was also applied: boron (B): $0.81 \mathrm{mg} \mathrm{dm}^{-3}$ of $\mathrm{H}_{3} \mathrm{BO}_{3}$, copper $(\mathrm{Cu})$ : $1.33 \mathrm{mg} \mathrm{dm}^{-3}$ of $\mathrm{CuSO}_{4} .5 \mathrm{H}_{2} \mathrm{O}$, molybdenum (Mo): $0.15 \mathrm{mg} \mathrm{dm}^{-3}$ of $\left(\mathrm{NH}_{4}\right)_{6} \mathrm{Mo}_{7} \mathrm{O}_{24} \cdot 4 \mathrm{H}_{2} \mathrm{O}$, manganese (Mn): 3.66 $\mathrm{mg} \mathrm{dm}{ }^{-3}$ of $\mathrm{MnCl}_{2} . \mathrm{H} 2 \mathrm{O}$ and zinc $(\mathrm{Zn}): 4.0 \mathrm{mg} \mathrm{dm}^{-3}$ of $\mathrm{ZnSO}_{4}$.

Seeds of lima bean (Branquinha cv.) were aquired from producers of the region, and four seeds were sown per pot, with thinning at 15 days after emergence of the seedlings, leaving only one plant per pot. During the experiment 
period, soil moisture was maintained at $70 \%$ of the field capacity, controlled by daily weighing of the pots and adding distilled water.

After 60 days, in the pre-flowering phase, completely developed leaves were collected from the apical area, washed with distilled water and identified for further leaf analysis. Leaf samples were dried in an oven with air circulation at $60{ }^{\circ} \mathrm{C}$ until reaching constant weight and then processed in a Willey mill. For the analysis and determination of the nutritional contents, samples were digested using nitroperchloric acid, and the extracts were analyzed for phosphorus (colorimetry), potassium (flame photometry), calcium and magnesium (titulometry), while nitrogen contents were determined by the Kjeldahl method, after sulfur digestion (Embrapa 2009).

Table 1. Treatments obtained by the Baconian matrix with the doses of the macronutrients applied for the production of the lima bean

\begin{tabular}{|c|c|c|c|c|c|c|}
\hline \multirow{2}{*}{ Treatments } & \multicolumn{6}{|c|}{ Macronutrients } \\
\hline & $\mathbf{N}$ & $\mathbf{P}_{2} \mathbf{O}_{5}$ & $\mathbf{K}_{2} \mathbf{O}$ & $\mathbf{C a}$ & Mg & $\mathbf{S}$ \\
\hline & \multicolumn{3}{|c|}{ 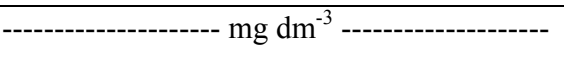 } & \multicolumn{2}{|c|}{ - } & $\mathrm{mg} \mathrm{dm}^{-3}$ \\
\hline $1^{*}$ & 20 & 100 & 60 & 1.2 & 0.4 & 20 \\
\hline 2 & 0 & 0 & 0 & 0 & 0 & 0 \\
\hline 3 & 10 & 100 & 60 & 1.2 & 0.4 & 20 \\
\hline 4 & 30 & 100 & 60 & 1.2 & 0.4 & 20 \\
\hline 5 & 40 & 100 & 60 & 1.2 & 0.4 & 20 \\
\hline 6 & 20 & 50 & 60 & 1.2 & 0.4 & 20 \\
\hline 7 & 20 & 150 & 60 & 1.2 & 0.4 & 20 \\
\hline 8 & 20 & 200 & 60 & 1.2 & 0.4 & 20 \\
\hline 9 & 20 & 100 & 30 & 1.2 & 0.4 & 20 \\
\hline 10 & 20 & 100 & 90 & 1.2 & 0.4 & 20 \\
\hline 11 & 20 & 100 & 120 & 1.2 & 0.4 & 20 \\
\hline 12 & 20 & 100 & 60 & 0.8 & 0.4 & 20 \\
\hline 13 & 20 & 100 & 60 & 1.6 & 0.4 & 20 \\
\hline 14 & 20 & 100 & 60 & 2.0 & 0.4 & 20 \\
\hline 15 & 20 & 100 & 60 & 1.2 & 0.2 & 20 \\
\hline 16 & 20 & 100 & 60 & 1.2 & 0.6 & 20 \\
\hline 17 & 20 & 100 & 60 & 1.2 & 0.8 & 20 \\
\hline 18 & 20 & 100 & 60 & 1.2 & 0.4 & 10 \\
\hline 19 & 20 & 100 & 60 & 1.2 & 0.4 & 30 \\
\hline 20 & 20 & 100 & 60 & 1.2 & 0.4 & 40 \\
\hline
\end{tabular}

Note. $*$ Reference doses values.

For the evaluation of the yield components of lima bean, pods were harvested at the stage of maturation, totaling 150 samples at the end of the experiment, which were identified and stored in paper bags. The yield of pods and dry grains were assessed by the following variables: i) pod length (LP, cm) — using a millimeter ruler; ii) weight of pods per plant (WP, g plant ${ }^{-1}$ ) - weight of all pods with grains harvested in the plot; (iii) number of pods per plant (NPP) - by the sum of all pods harvested in each plot; iv) number of grains per pod (NGP) - by counting the number of grains contained in each pod, with an average of 10 pods per plot; $v$ ) total number of grains per plant (NTG) - determined by the sum of all grains produced in plot e; vi) total grain weight per plant (WTG, g plant $^{-1}$ ) — obtained by weighing all the grains produced in the plot. Before weighing, beans were dried in a circulation oven at $60^{\circ} \mathrm{C}$ during $24 \mathrm{~h}$.

Data were submitted to analysis of variance and regression using the statistical program R 2.15 (R Development Core Team, 2012).

\section{Results and Discussion}

The average values for the production and nutritional status of the lima bean in the various evaluated characteristics are shown in Table 2 and 3, respectively. In general, the variables increased as a result of the application of increasing doses of macronutrients, evidencing the importance of the appropriate management of 
the crop fertilization to guarantee good yields, especially when cultivated in soils with low levels of nutrients, e.g., the Entisol Quartzipsamment.

Table 2. Avarege values of the macronutrients effect on the yield components of lima bean

\begin{tabular}{|c|c|c|c|c|c|c|c|c|c|c|c|}
\hline \multirow[t]{3}{*}{$\overline{\mathrm{Mac}}$} & \multirow{3}{*}{$\begin{array}{l}\text { Doses } \\
0\end{array}$} & \multirow{2}{*}{$\begin{array}{l}\mathrm{LP} \\
-----\mathrm{cm} \text {----- }\end{array}$} & \multicolumn{2}{|l|}{ WP } & \multicolumn{2}{|l|}{ NPP } & \multirow[t]{2}{*}{ NGP } & \multicolumn{2}{|l|}{ NTG } & \multicolumn{2}{|l|}{ WTG } \\
\hline & & & $--g p$ & $\operatorname{lant}^{-1}$--- & & & & & & $--g p$ & $\operatorname{lant}^{-1}---$ \\
\hline & & $5.03 \pm 0.46$ & 3.00 & \pm 0.03 & 2.00 & \pm 0.03 & $1.50 \pm 0.03$ & 3.00 & \pm 0.03 & 2.20 & \pm 0.03 \\
\hline $\mathrm{N}$ & 10 & $7.07 \pm 0.04$ & 20.53 & \pm 2.66 & 14.50 & \pm 3.28 & $1.94 \pm 0.25$ & 23.50 & \pm 4.13 & 14.77 & \pm 1.84 \\
\hline $\mathrm{N}$ & 20 & $8.51 \pm 0.23$ & 22.03 & \pm 4.21 & 15.75 & \pm 1.93 & $2.00 \pm 0.15$ & 26.25 & \pm 4.39 & 15.78 & \pm 2.94 \\
\hline $\mathrm{N}$ & 30 & $6.63 \pm 0.13$ & 18.33 & \pm 4.13 & 13.00 & \pm 3.03 & $1.96 \pm 0.23$ & 20.50 & \pm 6.44 & 12.90 & \pm 2.57 \\
\hline $\mathrm{N}$ & 40 & $6.44 \pm 0.28$ & 17.10 & \pm 1.15 & 11.75 & \pm 1.13 & $2.06 \pm 0.21$ & 22.75 & \pm 4.21 & 13.28 & \pm 0.41 \\
\hline $\mathrm{P}_{2} \mathrm{O}_{5}$ & 0 & $5.03 \pm 0.46$ & 3.00 & \pm 0.03 & 2.00 & \pm 0.03 & $1.50 \pm 0.03$ & 3.00 & \pm 0.03 & 2.20 & \pm 0.03 \\
\hline $\mathrm{P}_{2} \mathrm{O}_{5}$ & 50 & $7.19 \pm 0.51$ & 22.90 & \pm 2.66 & 13.50 & \pm 1.50 & $1.93 \pm 0.19$ & 30.75 & \pm 3.28 & 16.40 & \pm 1.58 \\
\hline $\mathrm{P}_{2} \mathrm{O}_{5}$ & 100 & $8.51 \pm 0.41$ & 22.03 & \pm 4.21 & 15.75 & \pm 1.93 & $2.00 \pm 0.15$ & 26.25 & \pm 4.39 & 15.78 & \pm 2.94 \\
\hline $\mathrm{P}_{2} \mathrm{O}_{5}$ & 150 & $6.71 \pm 0.46$ & 25.30 & \pm 2.06 & 17.88 & \pm 0.83 & $1.87 \pm 0.19$ & 18.33 & \pm 2.32 & 18.37 & \pm 1.65 \\
\hline $\mathrm{P}_{2} \mathrm{O}_{5}$ & 200 & $7.45 \pm 0.57$ & 25.93 & \pm 8.28 & 17.75 & \pm 6.51 & $2.16 \pm 0.17$ & 17.50 & \pm 3.86 & 18.00 & \pm 5.33 \\
\hline $\mathrm{K}_{2} \mathrm{O}$ & 0 & $5.03 \pm 0.46$ & 3.00 & \pm 0.03 & 2.00 & \pm 0.03 & $1.50 \pm 0.03$ & 3.00 & \pm 0.03 & 2.20 & \pm 0.03 \\
\hline $\mathrm{K}_{2} \mathrm{O}$ & 30 & $7.09 \pm 0.48$ & 26.35 & \pm 3.60 & 16.25 & \pm 3.42 & $2.13 \pm 0.15$ & 30.75 & \pm 2.25 & 18.03 & \pm 1.63 \\
\hline $\mathrm{K}_{2} \mathrm{O}$ & 60 & $8.51 \pm 0.50$ & 22.03 & \pm 4.21 & 15.75 & \pm 1.93 & $2.00 \pm 0.15$ & 26.25 & \pm 4.39 & 15.78 & \pm 2.94 \\
\hline $\mathrm{K}_{2} \mathrm{O}$ & 90 & $6.93 \pm 0.35$ & 21.23 & \pm 3.02 & 15.00 & \pm 2.12 & $2.30 \pm 0.22$ & 31.00 & \pm 4.49 & 15.28 & \pm 1.95 \\
\hline $\mathrm{K}_{2} \mathrm{O}$ & 120 & $7.37 \pm 0.35$ & 21.13 & \pm 4.43 & 15.00 & \pm 1.58 & $2.05 \pm 0.16$ & 33.50 & \pm 2.06 & 18.03 & \pm 0.85 \\
\hline $\mathrm{Ca}$ & 0 & $5.03 \pm 0.46$ & 3.00 & \pm 0.03 & 2.00 & \pm 0.03 & $1.50 \pm 0.03$ & 3.00 & \pm 0.03 & 2.20 & \pm 0.03 \\
\hline $\mathrm{Ca}$ & 0.8 & $7.05 \pm 0.41$ & 26.68 & \pm 2.56 & 16.25 & \pm 1.55 & $2.15 \pm 0.19$ & 31.00 & \pm 2.86 & 18.38 & \pm 2.07 \\
\hline $\mathrm{Ca}$ & 1.2 & $8.51 \pm 0.23$ & 22.03 & \pm 4.21 & 15.75 & \pm 1.93 & $2.00 \pm 0.15$ & 26.25 & \pm 4.39 & 15.78 & \pm 2.94 \\
\hline $\mathrm{Ca}$ & 1.6 & $7.62 \pm 0.69$ & 25.55 & \pm 4.36 & 12.00 & \pm 2.04 & $1.91 \pm 0.24$ & 19.75 & \pm 1.84 & 17.30 & \pm 3.15 \\
\hline $\mathrm{Ca}$ & 2.0 & $6.74 \pm 0.37$ & 19.40 & \pm 4.59 & 12.50 & \pm 3.52 & $1.70 \pm 0.04$ & 17.00 & \pm 4.49 & 13.13 & \pm 2.68 \\
\hline $\mathrm{Mg}$ & 0 & $5.03 \pm 0.46$ & 3.00 & \pm 0.03 & 2.00 & \pm 0.03 & $1.50 \pm 0.03$ & 3.00 & \pm 0.03 & 2.20 & \pm 0.03 \\
\hline $\mathrm{Mg}$ & 0.2 & $7.05 \pm 0.05$ & 24.38 & \pm 3.61 & 13.00 & \pm 2.12 & $1.89 \pm 0.30$ & 33.25 & \pm 9.70 & 16.15 & \pm 2.69 \\
\hline $\mathrm{Mg}$ & 0.4 & $8.51 \pm 0.26$ & 22.03 & \pm 4.21 & 15.75 & \pm 1.93 & $2.00 \pm 0.15$ & 26.25 & \pm 0.71 & 15.78 & \pm 2.94 \\
\hline $\mathrm{Mg}$ & 0.6 & $8.04 \pm 0.17$ & 25.83 & \pm 3.47 & 16.75 & \pm 0.63 & $2.23 \pm 0.15$ & 32.50 & \pm 8.26 & 23.98 & \pm 5.51 \\
\hline $\mathrm{Mg}$ & 0.8 & $7.19 \pm 0.64$ & 20.53 & \pm 4.31 & 10.50 & \pm 2.10 & $3.58 \pm 1.50$ & 30.75 & \pm 4.91 & 14.50 & \pm 3.11 \\
\hline $\mathrm{S}^{-}$ & 0 & $5.03 \pm 0.46$ & 3.00 & \pm 0.03 & 2.00 & \pm 0.03 & $1.50 \pm 0.03$ & 3.00 & \pm 0.03 & 2.20 & \pm 0.03 \\
\hline S & 10 & $6.50 \pm 0.39$ & 22.50 & \pm 2.16 & 15.00 & \pm 1.35 & $2.15 \pm 0.22$ & 19.25 & \pm 3.54 & 15.88 & \pm 1.77 \\
\hline S & 20 & $8.51 \pm 0.26$ & 22.03 & \pm 4.21 & 15.75 & \pm 1.93 & $2.00 \pm 0.15$ & 26.25 & \pm 4.39 & 15.78 & \pm 2.94 \\
\hline S & 30 & $6.09 \pm 0.68$ & 22.25 & \pm 5.62 & 14.75 & \pm 4.55 & $2.28 \pm 0.29$ & 42.00 & \pm 8.80 & 16.28 & \pm 3.82 \\
\hline S & 40 & $7.10 \pm 0.15$ & 24.85 & \pm 2.23 & 15.25 & \pm 0.75 & $1.93 \pm 0.15$ & 25.50 & \pm 3.66 & 19.55 & \pm 3.11 \\
\hline
\end{tabular}

Note. LP: length of the pod; WP: pod weight; NPP: number of pod per plant; NGP: number of grains per pod; NTG: total number of grains per plant; WTG: total weight of grains per plant. \pm standard error of average values $(\mathrm{n}=4)$. 
Table 3. Avarege values of the macronutrients effect on the nutrition of lima bean

\begin{tabular}{|c|c|c|c|c|c|c|c|c|c|c|c|c|}
\hline \multirow{3}{*}{$\begin{array}{l}\text { Macronutrient } \\
\mathrm{N}\end{array}$} & \multirow{3}{*}{$\begin{array}{l}\text { Doses } \\
0\end{array}$} & \multicolumn{2}{|l|}{$\mathrm{N}$} & \multicolumn{2}{|l|}{$\mathrm{P}$} & \multicolumn{2}{|l|}{$\mathrm{K}$} & \multicolumn{2}{|l|}{$\mathrm{Ca}$} & \multicolumn{2}{|l|}{$\mathrm{Mg}$} & \multirow{2}{*}{$\begin{array}{l}S \\
\end{array}$} \\
\hline & & & & & & & & & & & & \\
\hline & & 27.44 & \pm 0.03 & 3.28 & \pm 0.54 & 6.00 & \pm 0.03 & 5.44 & \pm 0.03 & 8.26 & \pm 0.03 & $1.58 \pm 0.03$ \\
\hline $\mathrm{N}$ & 10 & 22.98 & \pm 2.71 & 4.80 & \pm 0.43 & 23.60 & \pm 1.66 & 11.92 & \pm 0.68 & 7.82 & \pm 0.89 & $1.61 \pm 0.11$ \\
\hline $\mathrm{N}$ & 20 & 15.78 & \pm 1.31 & 5.41 & \pm 0.58 & 28.57 & \pm 0.40 & 13.04 & \pm 1.25 & 4.94 & \pm 0.59 & $1.52 \pm 0.01$ \\
\hline $\mathrm{N}$ & 30 & 26.75 & \pm 2.13 & 5.23 & \pm 0.35 & 20.34 & \pm 3.00 & 16.32 & \pm 4.42 & 5.42 & \pm 0.87 & $1.64 \pm 0.04$ \\
\hline $\mathrm{N}$ & 40 & 28.81 & \pm 0.97 & 4.62 & \pm 0.32 & 21.68 & \pm 0.33 & 8.48 & \pm 0.74 & 3.07 & \pm 0.95 & $1.71 \pm 0.14$ \\
\hline $\mathrm{P}_{2} \mathrm{O}_{5}$ & 0 & 27.44 & \pm 0.03 & 3.28 & \pm 0.54 & 6.00 & \pm 0.03 & 5.44 & \pm 0.03 & 8.26 & \pm 0.03 & $1.58 \pm 0.03$ \\
\hline $\mathrm{P}_{2} \mathrm{O}_{5}$ & 50 & 17.49 & \pm 4.53 & 4.22 & \pm 0.08 & 21.61 & \pm 0.52 & 8.00 & \pm 1.61 & 6.72 & \pm 1.31 & $1.46 \pm 0.06$ \\
\hline $\mathrm{P}_{2} \mathrm{O}_{5}$ & 100 & 15.78 & \pm 1.31 & 5.41 & \pm 0.31 & 28.57 & \pm 0.40 & 13.04 & \pm 1.25 & 4.94 & \pm 0.59 & $1.52 \pm 0.01$ \\
\hline $\mathrm{P}_{2} \mathrm{O}_{5}$ & 150 & 26.07 & \pm 5.46 & 4.81 & \pm 0.38 & 25.88 & \pm 3.21 & 10.16 & \pm 0.63 & 4.46 & \pm 0.88 & $1.59 \pm 0.08$ \\
\hline $\mathrm{P}_{2} \mathrm{O}_{5}$ & 200 & 24.01 & \pm 5.89 & 4.91 & \pm 0.46 & 23.78 & \pm 1.86 & 8.64 & \pm 0.91 & 4.03 & \pm 0.72 & $1.62 \pm 0.12$ \\
\hline $\mathrm{K}_{2} \mathrm{O}$ & 0 & 27.44 & \pm 0.03 & 3.28 & \pm 0.54 & 6.00 & \pm 0.03 & 5.44 & \pm 0.03 & 8.26 & \pm 0.03 & $1.58 \pm 0.03$ \\
\hline $\mathrm{K}_{2} \mathrm{O}$ & 30 & 22.64 & \pm 6.20 & 5.06 & \pm 0.31 & 27.17 & \pm 2.06 & 6.96 & \pm 0.40 & 5.55 & \pm 0.89 & $1.51 \pm 0.05$ \\
\hline $\mathrm{K}_{2} \mathrm{O}$ & 60 & 15.78 & \pm 1.31 & 5.41 & \pm 0.41 & 28.57 & \pm 0.40 & 13.04 & \pm 1.25 & 4.94 & \pm 0.59 & $1.52 \pm 0.01$ \\
\hline $\mathrm{K}_{2} \mathrm{O}$ & 90 & 18.18 & \pm 5.38 & 4.69 & \pm 0.22 & 21.80 & \pm 1.31 & 9.20 & \pm 0.56 & 4.11 & \pm 1.75 & $1.42 \pm 0.06$ \\
\hline $\mathrm{K}_{2} \mathrm{O}$ & 120 & 13.38 & \pm 0.86 & 4.63 & \pm 0.35 & 22.94 & \pm 1.46 & 9.60 & \pm 1.46 & 4.03 & \pm 0.31 & $1.43 \pm 0.13$ \\
\hline $\mathrm{Ca}$ & 0 & 27.44 & \pm 0.03 & 3.28 & \pm 0.54 & 6.00 & \pm 0.03 & 5.44 & \pm 0.03 & 8.26 & \pm 0.03 & $1.58 \pm 0.03$ \\
\hline $\mathrm{Ca}$ & 0,8 & 18.87 & \pm 5.15 & 4.83 & \pm 0.33 & 27.10 & \pm 3.60 & 7.04 & \pm 1.93 & 6.67 & \pm 1.91 & $1.65 \pm 0.09$ \\
\hline $\mathrm{Ca}$ & 1,2 & 15.78 & \pm 1.31 & 5.41 & \pm 0.43 & 28.57 & \pm 0.40 & 13.04 & \pm 1.25 & 4.94 & \pm 0.59 & $1.52 \pm 0.01$ \\
\hline $\mathrm{Ca}$ & 1,6 & 18.85 & \pm 3.28 & 5.32 & \pm 0.48 & 25.60 & \pm 0.69 & 14.51 & \pm 1.49 & 3.94 & \pm 0.69 & $1.43 \pm 0.10$ \\
\hline $\mathrm{Ca}$ & 2.0 & 22.98 & \pm 4.28 & 4.55 & \pm 0.14 & 24.30 & \pm 2.07 & 12.05 & \pm 0.89 & 8.45 & \pm 0.67 & $1.56 \pm 0.04$ \\
\hline $\mathrm{Mg}$ & 0 & 27.44 & \pm 0.03 & 3.28 & \pm 0.54 & 6.00 & \pm 0.03 & 5.44 & \pm 0.03 & 8.26 & \pm 0.03 & $1.58 \pm 0.03$ \\
\hline $\mathrm{Mg}$ & 0.2 & 22.64 & \pm 5.27 & 4.65 & \pm 0.38 & 22.18 & \pm 1.48 & 8.64 & \pm 1.51 & 2.88 & \pm 1.10 & $1.53 \pm 0.09$ \\
\hline $\mathrm{Mg}$ & 0.4 & 15.78 & \pm 1.31 & 5.41 & \pm 0.29 & 28.57 & \pm 0.40 & 13.04 & \pm 1.25 & 4.94 & \pm 0.59 & $1.52 \pm 0.01$ \\
\hline $\mathrm{Mg}$ & 0.6 & 18.18 & \pm 4.60 & 5.00 & \pm 0.14 & 27.54 & \pm 0.72 & 10.56 & \pm 0.73 & 5.42 & \pm 1.21 & $1.86 \pm 0.16$ \\
\hline $\mathrm{Mg}$ & 0.8 & 22.98 & \pm 4.09 & 4.71 & \pm 0.41 & 27.43 & \pm 1.97 & 9.60 & \pm 1.13 & 10.75 & \pm 0.95 & $1.55 \pm 0.15$ \\
\hline $\mathrm{S}^{-}$ & 0 & 27.44 & \pm 0.03 & 3.28 & \pm 0.54 & 6.00 & \pm 0.03 & 5.44 & \pm 0.03 & 8.26 & \pm 0.03 & $1.58 \pm 0.03$ \\
\hline S & 10 & 19.89 & \pm 5.21 & 5.02 & \pm 0.41 & 22.55 & \pm 0.98 & 8.56 & \pm 1.09 & 6.19 & \pm 1.81 & $1.44 \pm 0.09$ \\
\hline S & 20 & 15.78 & \pm 1.31 & 5.41 & \pm 0.27 & 28.57 & \pm 0.40 & 13.04 & \pm 1.25 & 4.94 & \pm 0.59 & $1.52 \pm 0.01$ \\
\hline S & 30 & 20.24 & \pm 3.77 & 4.33 & \pm 0.29 & 28.45 & \pm 4.29 & 10.80 & \pm 1.51 & 3.98 & \pm 2.21 & $1.53 \pm 0.05$ \\
\hline S & 40 & 13.72 & \pm 0.56 & 4.85 & \pm 0.26 & 26.73 & \pm 2.41 & 9.84 & \pm 1.26 & 5.62 & \pm 0.92 & $1.45 \pm 0.02$ \\
\hline
\end{tabular}

Note. Leaf contents of nitrogen $(\mathrm{N})$, phosphorus $(\mathrm{P})$, potassium $(\mathrm{K})$, calcium $(\mathrm{Ca})$, magnesium $(\mathrm{Mg})$ and sulfur (S). \pm standard error of average values $(n=4)$.

\subsection{Nitrogen}

With the exception of the number of grains per pod (NGP), nitrogen (N) was significant over the other nutrients, presenting a quadratic behavior (Table 4). Regarding nutrient leaf contents (N, P, K, Ca, Mg and S), the effects on $\mathrm{P}, \mathrm{K}$ and $\mathrm{Ca}$ followed a quadratic adjustment and $\mathrm{Mg}$ a linear adjustment.

Because it is a genetically characteristic of the plant, NGP, which showed little effect on this production characteristic, is the least component of production influenced by the environment (Guimarães, Martins, Silva, Ferraz, \& Oliveira, 2007; Oliveira,Torres, \& Bebedito., 2011).

Regarding pod length (LP), the average of $7.8 \mathrm{~cm}$ was reached in the dose of $23 \mathrm{mg} \mathrm{N} \mathrm{dm}$. The value found for this variable is within those registered in the literature, which is in the range of 4.8 to $8.9 \mathrm{~cm}$; this variation is due to different genetic materials (Guimarães et al., 2007; Santos, Corlett, Mendes, \& Wanderley, 2002).

The pod weight (WP) and the number of pods per plant (NPP) presented values of $22.84 \mathrm{~g}$ and 16.26 pods, respectively, at the dose of $24 \mathrm{mg} \mathrm{N} \mathrm{dm}^{-3}$. For the number of grains per plant (NTG) and total grain weight (WTG), a maximum yield of 27 grains and 17 grams at a dose of $25 \mathrm{mg} \mathrm{N} \mathrm{dm}^{-3}$ were observed. When evaluating the production of pods and dry grains per plant, Alves et al. (2008) obtained average values of 125.9 and $35.3 \mathrm{~g}$, 
respectively, using the doses of 21.4 and $26.6 \mathrm{tha}^{-1}$ of bovine manure in the presence of NPK $\left(30 \mathrm{~kg} \mathrm{~N} \mathrm{ha}^{-1}\right)$, which was also measured at 30 and 60 days after planting.

Table 4. Estimates of the nitrogen effect on the yield components and nutrition of lima bean

\begin{tabular}{llll}
\hline Variables & Equations & & RD \\
\hline LP & $\hat{Y}=5.1495+0.2436 \mathrm{x}^{* *}-0.0054 \mathrm{x}^{2 * *}$ & $\mathrm{R}^{2}=0.78$ & 23 \\
WP & $\hat{Y}=4.8950+1.4800 \mathrm{x}^{* *}-0.0305 \mathrm{x}^{2 * *}$ & $\mathrm{R}^{2}=0.85$ & 24 \\
NPP & $\hat{Y}=3.3000+1.0800 \mathrm{x} *-0.0225 \mathrm{x}^{2 * *}$ & $\mathrm{R}^{2}=0.86$ & 24 \\
NGP & $\hat{Y}=\bar{Y}=1.9$ & - & 10 \\
NTG & $\hat{Y}=5.4714+1.6507 \mathrm{x} * *-0.0321 \mathrm{x}^{2 *}$ & $\mathrm{R}^{2}=0.80$ & 25 \\
WTG & $\hat{Y}=3.6881+1.0104 \mathrm{x}^{* *}-0.0201 \mathrm{x}^{2 * *}$ & $\mathrm{R}^{2}=0.82$ & 25 \\
N & $\hat{Y}=\bar{Y}=26.15$ & - & 10 \\
P & $\hat{Y}=3.2464+0.2283 \mathrm{x}^{* *}-0.0049 \mathrm{x}^{2 * *}$ & $\mathrm{R}^{2}=0.90$ & 23 \\
K & $\hat{Y}=7.8872+1.5869 \mathrm{x}^{* *}-0.0326 \mathrm{x}^{2 * *}$ & $\mathrm{R}^{2}=0.80$ & 23 \\
Ca & $\hat{Y}=5.1611+0.8613 \mathrm{x}^{* *}-0.0189 \mathrm{x}^{2 * *}$ & $\mathrm{R}^{2}=0.87$ & 23 \\
Mg & $\hat{Y}=8.4576-0.1276 \mathrm{x}^{* *}$ & $\mathrm{R}^{2}=0.89$ & 10 \\
S & $\hat{Y}=\bar{Y}=1.55$ & - & 10 \\
\hline
\end{tabular}

Note. RD: recommended dose in $\mathrm{mg} \mathrm{dm}^{-3}$; LP: length of the pod, in $\mathrm{cm}$; WP: pod weight, in $\mathrm{g}$ plant ${ }^{-1}$; NPP: number of pod per plant; NGP: number of grains per pod; NTG: total number of grains per plant; WTG: total weight of grains per plant, in $\mathrm{g}$ plant ${ }^{-1}$; and leaf contents of $\mathrm{N}, \mathrm{P}, \mathrm{K}, \mathrm{Ca}, \mathrm{Mg}$ and $\mathrm{S}$, in $\mathrm{g} \mathrm{kg}^{-1}$. $^{*}$ and ** significant at 5 and $1 \%$ probability, respectively, by the $\mathrm{F}$ test.

Contents of $\mathrm{P}, \mathrm{K}$ and Ca were 5.90, 27.19 and $15 \mathrm{~g} \mathrm{~kg}^{-1}$, respectively, for the dose of $23 \mathrm{mg} \mathrm{N} \mathrm{dm}^{-3}$. Phosphorous (P) and $\mathrm{N}$ presented synergism, which caused an increase of $\mathrm{P}$ absorption when ammoniacal nitrogen was used (Hanway \& Olson, 1980).

The increase of $\mathrm{N}$ doses reduced the $\mathrm{Mg}$ contents in the aerial part of lima bean by $62 \%$ compared to the control with no fertilization. However, the average value of $3.7 \mathrm{~g} \mathrm{Mg} \mathrm{kg}^{-1}$ is still suitable for most grains (Malavolta, 2006) Thus, this result is attributed to the greater development of the crop with nitrogen fertilization.

It is important to emphasize that although $\mathrm{N}$ is a determinant nutrient in the development and production of beans, doses of mineral fertilizers are usually required in smaller quantities when compared to other crops. This is justified by the fact that beans establish symbiosis with diazotrophic bacteria and supplies most of the plant demand for atmospheric N (Barbosa et al., 2017). In this study, it was possible to verify the occurrence of nodules in bean roots, which may have reduced the demand for mineral $\mathrm{N}$, without damaging the development of the plants.

\subsection{Phosphorous}

The application of phosphorus (P) to the production components and nutritional status of lima bean $\mathrm{s}$ (Table 5) showed a quadratic adjustment for LP, WP, NTG, WTG, Ca and K contents and a linear adjustment for NPP, P and Mg contents.

The maximum LP was $10.31 \mathrm{~cm}$ at the dose of $200 \mathrm{mg}_{2} \mathrm{O}_{5} \mathrm{dm}^{-3}$. For WP, which is directly associated with crop productivity, there was an increase of $29.71 \mathrm{~g}$ with the dose of $157 \mathrm{mg} \mathrm{P}_{2} \mathrm{O}_{5} \mathrm{dm}^{-3}$. Phosphate fertilization increased NPP from 2.0 to 17.7 , representing an increase of $89 \%$ at the dose of $200 \mathrm{mg} \mathrm{P}_{2} \mathrm{O}_{5} \mathrm{dm}^{-3}$. NTG and WTG reached values of 28 grains and $20.50 \mathrm{~g}$, in the doses of 111 and $153 \mathrm{mg} \mathrm{P}_{2} \mathrm{O}_{5} \mathrm{dm}^{-3}$, respectively.

The increases obtained for the production components were satisfactory, demonstrating that lima bean $\mathrm{s}$ were responsive to phosphate fertilization. Phosphorous is determinant for their productivity, since this nutrient acts directly in the synthesis of ATP, and consequently, in all the processes that require energy, such as in the uptake and assimilation of nutrients, photosynthesis and carbohydrate translocation (Malavolta, 2006; Marschner, 2012). In their study, Oliveira et al. (2004) evaluated the production of lima bean "Orelha de Vó" cultivar in a Regolitic Neosol, with different doses of $\mathrm{P}_{2} \mathrm{O}_{5}\left(0,100,200,300,400\right.$ and $\left.500 \mathrm{~kg} \mathrm{ha}^{-1}\right)$ and found a positive response for green and dry grains, recommending the application of 291 and $281 \mathrm{~kg} \mathrm{P}_{2} \mathrm{O}_{5} \mathrm{ha}^{-1}$. 
Table 5. Estimates of the phosphorus effect on the yield components and nutrition of lima bean

\begin{tabular}{llll}
\hline Variables & Equations & RD \\
\hline LP & $\hat{Y}=5.2332+0.0451 \mathrm{x}^{* *}-0.0001 \mathrm{x}^{2 * *}$ & $\mathrm{R}^{2}=0.67$ & 200 \\
WP & $\hat{Y}=5.1103+0.3137 \mathrm{x}^{* *}-0.0010 \mathrm{x}^{2 *}$ & $\mathrm{R}^{2}=0.90$ & 157 \\
NPP & $\widehat{Y}=6.2000+0.0717 \mathrm{x}^{* *}$ & $\mathrm{R}^{2}=0.74$ & 200 \\
NGP & $\widehat{Y}=\bar{Y}=1.9$ & - & 50 \\
NTG & $\widehat{Y}=7.1953+0.3793 \mathrm{x}^{* *}-0.0017 \mathrm{x}^{2 * *}$ & $\mathrm{R}^{2}=0.64$ & 111 \\
WTG & $\widehat{Y}=3.73228+0.2152 \mathrm{x}^{* *}-0.0007 \mathrm{x}^{2 *}$ & $\mathrm{R}^{2}=0.88$ & 153 \\
N & $\widehat{Y}=\bar{Y}=22.15$ & - & 50 \\
P & $\widehat{Y}=3.4435+0.0076 \mathrm{x}^{* *}$ & $\mathrm{R}^{2}=0.80$ & 200 \\
K & $\hat{Y}=6.7641+0.3371 \mathrm{x}^{* *}-0.0012 \mathrm{x}^{2 * *}$ & $\mathrm{R}^{2}=0.96$ & 140 \\
Ca & $\widehat{Y}=5.0468+0.1090 \mathrm{x}^{* *}-0.0004 \mathrm{x}^{2 * *}$ & $\mathrm{R}^{2}=0.82$ & 136 \\
Mg & $\hat{Y}=7.8240-0.0214 \mathrm{x}^{* *}$ & $\mathrm{R}^{2}=0.92$ & 200 \\
S & $\widehat{Y}=\bar{Y}=1.55$ & - & 50
\end{tabular}

Note. RD: recommended dose in $\mathrm{mg} \mathrm{dm}^{-3}$; LP: length of the pod, in $\mathrm{cm}$; WP: pod weight, in $\mathrm{g}_{\text {plant }}{ }^{-1}$; NPP: number of pod per plant; NGP: number of grains per pod; NTG: total number of grains per plant; WTG: total weight of grains per plant, in $\mathrm{g} \mathrm{plant}^{-1}$; and leaf contents of $\mathrm{N}, \mathrm{P}, \mathrm{K}, \mathrm{Ca}, \mathrm{Mg}$ and $\mathrm{S}$, in $\mathrm{g} \mathrm{kg}^{-1}$ * $^{*}$ and ${ }^{* *}$ significant at 5 and $1 \%$ probability, respectively, by the $\mathrm{F}$ test.

Phosphorous content increased linearly with $\mathrm{P}_{2} \mathrm{O}_{5}$ doses, with a maximum concentration of $4.9 \mathrm{~g} \mathrm{P} \mathrm{kg}^{-1}$ in the application of $200 \mathrm{mg} \mathrm{P} \mathrm{P}_{5} \mathrm{dm}^{-3}$, indicating that the greater availability of $\mathrm{P}$ in soil reflects in the greater absorption and incorporation of this nutrient in the biomass, with a consequent increase in of lima bean production. Linear responses in the accumulation of $\mathrm{P}$ with phosphate fertilization are widely reported in the literature for different cultivars of the genus Phaseolus (A. M. T. Alovisi, Furtini Neto, Carneiro, Curi, \& A. A. Alovisi, 2014; Santos et al., 2011; Silva et al., 2014).

For $\mathrm{K}$ and $\mathrm{Ca}$ contents, the maximum concentrations obtained were 30.43 and $12.46 \mathrm{~g} \mathrm{~kg}^{-1}$ at doses of 140 and 136 mg $\mathrm{P}_{2} \mathrm{O}_{5} \mathrm{dm}^{-3}$, respectively. For the highest dose of $\mathrm{P}_{2} \mathrm{O}_{5}$ the $\mathrm{Mg}$ content was reduced by $51 \%$ in relation to the treatment without fertilization, decreasing from 8.25 to $4.03 \mathrm{~g} \mathrm{Mg} \mathrm{kg}^{-1}$; however, this behavior indicates that a nutrient dilution effect occurred when there was an increase in phosphate fertilization. Similar effects for $\mathrm{Ca}$ and Mg uptake under P rates were observed by Salinas, Sánchez, Ruíz, Lao, and Romero (2013) for Phaseolus vulgaris $\mathrm{L}$. cv. Strike, who correlated the higher cation uptake $\left(\mathrm{K}^{+}, \mathrm{Ca}^{2+}\right.$ and $\left.\mathrm{Mg}^{2+}\right)$ to the higher ATPase activity with the increase of $\mathrm{P}$, suggesting the favoring the co-transport of these nutrients.

In general, nutrient availability in the soil directly influences the productive response of crops to mineral fertilization. In the present study, the positive response to phosphate fertilization for the production and nutrition of lima bean can be attributed to the initial low levels of this nutrient in the soil under cultivation. Another important factor is that in this soil class, due to the lower content of clay and oxides of $\mathrm{Fe}$ and $\mathrm{Al}$, there is less fixation of the P, which makes it more available to the plants (Sandim, Bull, Furim, Lima, \& Garcia, 2014; Santos, Oliveira, Souza, Salcedo, \& Silva, 2016).

\subsection{Potassium}

The effect of potassium (K), except for $\mathrm{N}$ and $\mathrm{S}$ contents, followed a quadratic adjustment for the production components and nutritional contents (Table 6). The maximum LP found was $8.6 \mathrm{~cm}$ at the dose of $93 \mathrm{mg} \mathrm{K}_{2} \mathrm{O} \mathrm{dm}^{-3}$. WP and NPP presented values of $25.96 \mathrm{~g}$ and 18.16 pods at the doses of 76 and $81 \mathrm{mg} \mathrm{K}_{2} \mathrm{O} \mathrm{dm}^{-3}$, respectively. Considering all production components, the number of pods is one of the most important in the determination of bean crop yield, especially because it presents a high and consistent correlation with grain production (Fageria \& Santos, 2008), increasing with potassium fertilization.

Regarding NGP, potassium fertilization provided an average of 2.5 grains per pod at a dose of $84 \mathrm{mg} \mathrm{K}_{2} \mathrm{O} \mathrm{dm}^{-3}$. The value found in this production component corroborates with Guimarães et al. (2007), in a study of the morphological characteristics of lima bean.

The NTG and WTG yields obtained in the doses of 93 and $86 \mathrm{mg} \mathrm{K}_{2} \mathrm{O} \mathrm{dm}{ }^{-3}$ of were 34.6 grains and $18.81 \mathrm{~g}$, respectively. Potassium is one of the most absorbed and exported nutrient in lima bean, acting on the osmotic and ionic regulation and as a cofactor and activator for many enzymes of carbohydrate and protein metabolism (Wang $\& \mathrm{Wu}, 2017)$. Thus, its adequate supply, in addition to increasing the productivity of the bean in the present study, 
can improve the nutritional value and quality by increasing the content of proteins and oils, as well as avoiding the production of small, wrinkled and deformed beans (Fageria \& Melo, 2014).

Table 6. Estimates of the potassium effect on the yield components and nutrition of lima bean

\begin{tabular}{llll}
\hline Variables & Equations & & RD \\
\hline LP & $\hat{Y}=5.1845+0.0746 \mathrm{x}^{* *}-0.0004 \mathrm{x}^{2 * *}$ & $\mathrm{R}^{2}=0.76$ & 93 \\
WP & $\hat{Y}=6.3235+0.5168 \mathrm{x}^{* *}-0.0034 \mathrm{x}^{2 * *}$ & $\mathrm{R}^{2}=0.70$ & 76 \\
NPP & $\hat{Y}=3.7428+0.3563 \mathrm{x}^{* *}-0.0022 \mathrm{x}^{2 * *}$ & $\mathrm{R}^{2}=0.82$ & 81 \\
NGP & $\hat{Y}=1.5507+0.0168 \mathrm{x}^{* *}-0.0001 \mathrm{x}^{2 *}$ & $\mathrm{R}^{2}=0.80$ & 84 \\
NTG & $\hat{Y}=6.7571+0.5970 \mathrm{x} *-0.0032 \mathrm{x}^{2 * *}$ & $\mathrm{R}^{2}=0.79$ & 93 \\
WTG & $\hat{Y}=4.5942+0.3287 \mathrm{x}^{* *}-0.0019 \mathrm{x}^{2 * *}$ & $\mathrm{R}^{2}=0.71$ & 87 \\
N & $\hat{Y}=\bar{Y}=19.48$ & - & 30 \\
P & $\hat{Y}=3.3976+0.0694 \mathrm{x}^{* *}-0.0005 \mathrm{x}^{2 * *}$ & $\mathrm{R}^{2}=0.77$ & 70 \\
K & $\hat{Y}=8.7027+0.5543 \mathrm{x}^{* *}-0.0038 \mathrm{x}^{2 * *}$ & $\mathrm{R}^{2}=0.76$ & 73 \\
Ca & $\hat{Y}=5.1274+0.1224 \mathrm{x}^{* *}-0.0007 \mathrm{x}^{2 * *}$ & $\mathrm{R}^{2}=0.76$ & 87 \\
Mg & $\hat{Y}=7.360-0.033 \mathrm{x}^{* *}$ & $\mathrm{R}^{2}=0.82$ & 30 \\
S & $\hat{Y}=\bar{Y}=1.49$ & - & 30
\end{tabular}

Note. RD: recommended dose in $\mathrm{mg} \mathrm{dm}^{-3}$; LP: length of the pod, in $\mathrm{cm}$; WP: pod weight, in $\mathrm{g}_{\text {plant }}{ }^{-1}$; NPP: number of pod per plant; NGP: number of grains per pod; NTG: total number of grains per plant; WTG: total weight of grains per plant, in $\mathrm{g}_{\text {plant }}{ }^{-1}$; and leaf contents of $\mathrm{N}, \mathrm{P}, \mathrm{K}, \mathrm{Ca}, \mathrm{Mg}$ and $\mathrm{S}$, in $\mathrm{g} \mathrm{kg}^{-1}$. * and ** significant at 5 and $1 \%$ probability, respectively, by the $\mathrm{F}$ test.

$\mathrm{P}, \mathrm{K}$ and $\mathrm{Ca}$ bean contents were $5.80,28.91$ and $10.47 \mathrm{~g} \mathrm{~kg}^{-1}$ at the doses of 70,73 and $87 \mathrm{mg} \mathrm{K}_{2} \mathrm{O} \mathrm{dm}$, respectively. The concentration of $\mathrm{Mg}$ decreased from 8.26 to $4.03 \mathrm{~g} \mathrm{~kg}^{-1}$ with increasing doses of $\mathrm{K}_{2} \mathrm{O}$. It is noted that up to the dose of $90 \mathrm{mg} \mathrm{K}_{2} \mathrm{O} \mathrm{dm}{ }^{-3}$, the nutritional balance is still maintained for the contents of $\mathrm{P}, \mathrm{K}, \mathrm{Ca}$ and $\mathrm{Mg}$, since these levels are considered adequate for the cultivation of most bean cultivars. This results ought to be

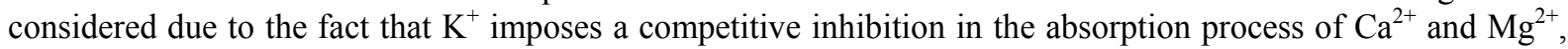
especially because of its monovalent nature and lower degree of hydration compared to divalent ions, presenting higher velocity when crossing the plasma membrane (Véry, Nieves-Cordones, Daly, Fizames, \& Sentenac, 2014).

The content of $\mathrm{K}$ in the soil of the present study is low (Comissão de Fertilidade de Solos do Estado de Minas Gerais, 1999), which may have contributed to obtain answers in the production and nutrition of lima bean. However, in addition to the inherent requirement of the crop, it should be taken into account that Entisol Quartzipsamment have high potential for K losses by leaching (Werle, Garcia, \& Rosolem 2009), which requires the gradual application of higher doses of $\mathrm{K}$.

\subsection{Calcium}

With the exception of NGP, calcium (Ca) doses influenced the production components following a quadratic adjustment (Table 7). The effect of $\mathrm{Ca}$ application on bean nutrition for $\mathrm{P}$ and $\mathrm{K}$ also presented a quadratic adjustment, and $\mathrm{Ca}$ and $\mathrm{Mg}$ had a linear adjustment.

A LP of $7.52 \mathrm{~cm}$ were found in the dose of $1.31 \mathrm{cmol}_{\mathrm{c}} \mathrm{Ca} \mathrm{dm}^{-3}$. WP and NPP had averages of $26.22 \mathrm{~g}$ and 15.91 pods for the doses of 1.27 and $1.24 \mathrm{cmol}_{\mathrm{c}} \mathrm{Ca} \mathrm{dm}{ }^{-3}$, respectively. Since $\mathrm{Ca}$ acts positively on pollen grain germination and on pollen tube growth, this nutrient certainly favors the fixation of flower buds and the formation of pods with consequent increase in NPP of lima bean.

The NTG and WTG presented yields of 28.20 and $18.16 \mathrm{~g}$ at the doses of 1.15 and $1.25 \mathrm{cmol}_{\mathrm{c}} \mathrm{Ca} \mathrm{dm}^{-3}$, respectively. The results of the present study corroborate with Bevilaqua, Silva Filho, and Possent (2002), who observed the effect of Ca and B applications with NPP (9.2 pods), NGP (1.6 grain) and WTG (18.0 g) using cv. BR 16. 
Table 7. Estimates of the calcium effect on the yield components and nutrition of lima bean

\begin{tabular}{llll}
\hline Variables & Equations & & RD \\
\hline LP & $\hat{Y}=4.9924+3.8529 \mathrm{x}^{* *}-1.4633 \mathrm{x}^{2 * *}$ & $\mathrm{R}^{2}=0.99$ & 1.31 \\
WP & $\hat{Y}=3.6684+35.3244 \mathrm{x}^{* *}-13.8320 \mathrm{x}^{2 * *}$ & $\mathrm{R}^{2}=0.92$ & 1.27 \\
NPP & $\hat{Y}=2.5927+21.4400 \mathrm{x} * *-8.6259 \mathrm{x}^{2 * *}$ & $\mathrm{R}^{2}=0.89$ & 1.24 \\
NGP & $\widehat{Y}=\bar{Y}=1.9$ & - & 1.20 \\
NTG & $\hat{Y}=4.2658+42.2583 \mathrm{x}^{* *}-18.6314 \mathrm{x}^{2 * *}$ & $\mathrm{R}^{2}=0.88$ & 1.15 \\
WTG & $\hat{Y}=2.6297+24.7699 \mathrm{x}^{* *}-9.8478 \mathrm{x}^{2 * *}$ & $\mathrm{R}^{2}=0.94$ & 1.25 \\
N & $\widehat{Y}=\bar{Y}=20.78$ & - & 0.80 \\
P & $\hat{Y}=3.1599+4.3978 \mathrm{x}^{* *}-1.8357 \mathrm{x}^{2 * *}$ & $\mathrm{R}^{2}=0.80$ & 1.20 \\
K & $\hat{Y}=6.4938+33.8849 \mathrm{x}^{* *}-12.8078 \mathrm{x}^{2 * *}$ & - & 1.20 \\
Ca & $\widehat{Y}=5.5597+4.3358 \mathrm{x}^{* *}$ & $\mathrm{R}^{2}=0.71$ & 2.00 \\
Mg & $\hat{Y}=8.4022-2.7016 \mathrm{x}^{* *}$ & $\mathrm{R}^{2}=0.98$ & 0.80 \\
S & $\hat{Y}=\bar{Y}=1.54$ & - & 1.20
\end{tabular}

Note. RD: recommended dose in $\mathrm{mg} \mathrm{dm}^{-3}$; LP: length of the pod, in $\mathrm{cm}$; WP: pod weight, in $\mathrm{g}_{\text {plant }}{ }^{-1}$; NPP: number of pod per plant; NGP: number of grains per pod; NTG: total number of grains per plant; WTG: total weight of grains per plant, in $g$ plant ${ }^{-1}$; and leaf contents of $\mathrm{N}, \mathrm{P}, \mathrm{K}, \mathrm{Ca}, \mathrm{Mg}$ and $\mathrm{S}$, in $\mathrm{g} \mathrm{kg}^{-1}$. * and ** significant at 5 and $1 \%$ probability, respectively, by the $\mathrm{F}$ test.

Regarding leaf contents of $\mathrm{P}$ and $\mathrm{K}$, values of 5.79 and $28.90 \mathrm{~g} \mathrm{~kg}^{-1}$ were obtained for the doses of 1.20 and 1.32 $\mathrm{cmol}_{\mathrm{c}} \mathrm{Ca} \mathrm{dm}{ }^{-3}$, respectively. Phosphorous establishes a strong relationship with $\mathrm{Ca}$ in the soil because of the significant increase in $\mathrm{P}$ availability with liming (Santiago et al., 2017).

Ca content was increased by $58 \%$ with the application of $\mathrm{Ca}$ doses in relation to the treatment without fertilization, with an average content of $15 \mathrm{~g} \mathrm{~kg}^{-1}$, which is suitable for beans. Lima bean along the various species of Phaseolus $s p$. are considered excellent sources of $\mathrm{Ca}$ for human nutrition, with higher contents in chickpea and lentils (Jost, Ribeiro, Maziero, Cerutti, \& Rosa, 2009).

On the other hand, $\mathrm{Mg}$ contents were reduced approximately $60 \%$ with increasing $\mathrm{Ca}$ doses, evidencing the antagonistic effect frequently imposed by the increase of $\mathrm{Ca}$ concentration in the soil, which induce $\mathrm{Mg}$ deficiency in plants (Marschner, 2012).

In the Brazilian agriculture, liming is the main source of calcium fertilization for crops, configuring an easy, affordable and economically viable practice. In this sense, the average dose of $1.27 \mathrm{cmol}_{\mathrm{c}} \mathrm{Ca} \mathrm{dm}^{-3}$ that promoted gains in yield and nutritional balance in the present study is satisfactorily supplied by liming; therefore, it should be an indispensable practice for the cultivation of lima bean in Neosols.

\subsection{Magnesium}

With the exception of NGP, the production components (Table 8) were influenced by the application of magnesium $(\mathrm{Mg})$, as well as the contents of $\mathrm{P}, \mathrm{K}, \mathrm{Ca}$ and $\mathrm{Mg}$, following quadratic adjustments.

For LP, there was an increase of $8.25 \mathrm{~cm}$ for the dose of $0.50 \mathrm{cmol}_{\mathrm{c}} \mathrm{Mg} \mathrm{dm}^{-3}$, which is a result within the range of values found in the literature for lima bean (Guimarães et al., 2007; Santos, Corlett, Mendes, \& Wanderley, 2002). Similarly, there were increases of $26.88 \mathrm{~g}, 17.19$ pods, 37.4 grains and $18.16 \mathrm{~g}$ for WP, NPP, NTG and WTG, respectively, at the dose of $0.50 \mathrm{cmol}_{\mathrm{c}} \mathrm{Mg} \mathrm{dm}^{-3}$. Mg is directly related to crop productivity, since this nutrient has the main function of enzyme activator, being a cofactor of all phosphorylating enzymes (Chen, Peng, Li, \& Liao, 2017; Lin \& Nobel, 1971). 
Table 8. Estimates of the magnesium effect on the yield components and nutrition of lima bean

\begin{tabular}{llll}
\hline Variables & Equations & RD \\
\hline LP & $\hat{Y}=5.0265+12.7837 \mathrm{x}^{* *}-12.6562 \mathrm{x}^{2 * *}$ & $\mathrm{R}^{2}=0.99$ & 0.50 \\
WP & $\hat{Y}=5.1071+85.6785 \mathrm{x}^{* *}-84.2857 \mathrm{x}^{2 * *}$ & $\mathrm{R}^{2}=0.85$ & 0.50 \\
NPP & $\hat{Y}=2.2714+62.1607 \mathrm{x}^{* *}-64.7321 \mathrm{x}^{2 * *}$ & $\mathrm{R}^{2}=0.98$ & 0.50 \\
NGP & - & 0.20 \\
NTG & $\hat{Y}=\bar{Y}=2.23$ & 0.50 \\
WTG & $\widehat{Y}=6.2857+122.0178 \mathrm{x}^{* *}-118.3035 \mathrm{x}^{2 * *}$ & $\mathrm{R}^{2}=0.86$ & 0.50 \\
N & $\hat{Y}=2.5671+70.8910 \mathrm{x}^{* *}-68.3482 \mathrm{x}^{2 * *}$ & $\mathrm{R}^{2}=0.85$ & 0.20 \\
P & $\hat{Y}=\bar{Y}=21.40$ & - & 0.50 \\
K & $\widehat{Y}=3.3297+8.0122 \mathrm{x}^{* *}-8.0184 \mathrm{x}^{2 * *}$ & $\mathrm{R}^{2}=0.96$ & 0.56 \\
Ca & $\hat{Y}=6.9851+81.2335 \mathrm{x}^{* *}-71.4107 \mathrm{x}^{2 * *}$ & $\mathrm{R}^{2}=0.96$ & 0.50 \\
Mg & $\widehat{Y}=5.2365+26.8342 \mathrm{x}^{* *}-27.1428 \mathrm{x}^{2 * *}$ & $\mathrm{R}^{2}=0.87$ & 0.30 \\
S & $\hat{Y}=7.7797-24.5683 \mathrm{x}^{* *}+35.4151 \mathrm{x}^{2 * *}$ & $\mathrm{R}^{2}=0.89$ & 0.20 \\
\hline
\end{tabular}

Note. RD: recommended dose in $\mathrm{mg} \mathrm{dm}^{-3}$; LP: length of the pod, in $\mathrm{cm}$; WP: pod weight, in $\mathrm{g}_{\text {plant }}{ }^{-1}$; NPP: number of pod per plant; NGP: number of grains per pod; NTG: total number of grains per plant; WTG: total weight of grains per plant, in $\mathrm{g} \mathrm{plant}^{-1}$; and leaf contents of $\mathrm{N}, \mathrm{P}, \mathrm{K}, \mathrm{Ca}, \mathrm{Mg}$ and $\mathrm{S}$, in $\mathrm{g} \mathrm{kg}^{-1}$ * $^{*}$ and ${ }^{* *}$ significant at 5 and $1 \%$ probability, respectively, by the $\mathrm{F}$ test.

$\mathrm{P}$ content was increased with $\mathrm{Mg}$ doses, with an average value of $5.33 \mathrm{~g} \mathrm{~kg}^{-1}$ at a dose of $0.50 \mathrm{cmol}_{\mathrm{c}} \mathrm{Mg} \mathrm{dm}$. Because $\mathrm{Mg}$ acts as a P-carrier as a result of its participation in ATPases activation of the plasma membrane responsible for ionic absorption, $\mathrm{P}$ absorption is higher in the presence of $\mathrm{Mg}$ in soil (Marschner, 2012; Verbruggen \& Hermans, 2013).

For $\mathrm{K}$, the maximum concentration obtained was $30.08 \mathrm{~g} \mathrm{~kg}^{-1}$ at the dose of $0.56 \mathrm{cmol}_{\mathrm{c}} \mathrm{Mg} \mathrm{dm}^{-3}$. The high concentration of $\mathrm{Mg}$ in the soil can promote the displacement of $\mathrm{K}$ from the sorption complex to soil solution, and when this process supplants the competitive effect on the absorption of these nutrients, there is a higher uptake of $\mathrm{K}$ by plants (Soratto \& Crusciol, 2007).

The dose of $0.50 \mathrm{cmol}_{\mathrm{c}} \mathrm{Mg} \mathrm{dm}$ promoted maximum concentration of $\mathrm{Ca}$ and $\mathrm{Mg}, 11.89$ and $3.51 \mathrm{~g} \mathrm{~kg}^{-1}$, respectively. In a study with bean cultivars as a function of the application of Mg doses (Canizella, Moreira, Moraes, \& Fageria, 2016) verified increases in the uptake of $\mathrm{Ca}$ and $\mathrm{Mg}$ for cultivars.

In general, the dose of $0.50 \mathrm{cmol}_{\mathrm{c}} \mathrm{Mg} \mathrm{dm}^{-3}$ found in the present study is within the range recommended for most crops. It is confirmed that in the same way as $\mathrm{Ca}, \mathrm{Mg}$ nutrition is usually associated with agricultural correctives, which besides $\mathrm{pH}$ adjustment can also provide $\mathrm{Ca}$ and $\mathrm{Mg}$.

\subsection{Sulfur}

The application of sulfur (S) doses on the production components and nutritional status of lima bean (Table 9) presented a quadratic adjustment for WP, NPP, NTG and P and Ca contents, and a linear adjustment for LP and WTG.

LP values varied between 5.0 and $7.0 \mathrm{~cm}$, and the dose of $40 \mathrm{mg} \mathrm{S} \mathrm{dm}^{-3}$ promoted a $29 \%$ increase in relation to the treatment without fertilization. WP and NPP presented averages of $25.68 \mathrm{~g}$ and 17.7 pods at the doses of 29 and 27 $\mathrm{mg} \mathrm{S} \mathrm{dm}{ }^{-3}$, respectively. In a study evaluating the application of $\mathrm{S}$ on cover with bean in a no-tillage system, Crusciol, Soratto, Silva, and Lemos (2006) verified an increase in shoot dry matter production, number of pods per plant and yield grains. The authors also stated that in crops with high technological level, the increase in bean grain yield might be limited by the use of insufficient doses of $\mathrm{S}$.

For NTG, the maximum value was 34.16 grains at the dose of $28 \mathrm{mg} \mathrm{S} \mathrm{dm}{ }^{-3}$. WTG was increased by $89 \%$ when compared to the treatment without fertilization with the dose of $40 \mathrm{mg} \mathrm{S} \mathrm{dm}^{-3}$, with an average value of $19.55 \mathrm{~g}$ plant $^{-1}$. This result was satisfactory and indicates that $S$ increases the final yield of lima bean. Sulfur is involved in the constitution of amino acids, proteins and low molecular weight organic compounds, acting in vital processes such as photosynthesis and biological nitrogen fixation, therefore, being required in considerable amounts for the development of legumes, directly influencing the formation and filling of grains. 
Table 9. Estimates of the sulfur effect on the yield components and nutrition of lima bean

\begin{tabular}{llll}
\hline Variables & Equations & & RD \\
\hline LP & $\hat{Y}=5.6370+0.0374 \mathrm{x}^{*}$ & $\mathrm{R}^{2}=0.45$ & 40 \\
WP & $\hat{Y}=5.5064+1.3802 \mathrm{x}^{* *}-0.0236 \mathrm{x}^{2 *}$ & $\mathrm{R}^{2}=0.83$ & 29 \\
NPP & $\hat{Y}=3.4785+1.0267 \mathrm{x}^{* *}-0.0191 \mathrm{x}^{2 * *}$ & $\mathrm{R}^{2}=0.86$ & 27 \\
NGP & $\hat{Y}=\bar{Y}=1.97$ & - & 20 \\
NTG & $\hat{Y}=1.5428+2.2989 \mathrm{x}^{* *}-0.0405 \mathrm{x}^{2 * *}$ & $\mathrm{R}^{2}=0.87$ & 28 \\
WTG & $\hat{Y}=6.9150+0.35100 \mathrm{x} *$ & $\mathrm{R}^{2}=0.68$ & 40 \\
N & $\hat{Y}=\bar{Y}=18.21$ & - & 20 \\
P & $\hat{Y}=3.5313+0.1363 \mathrm{x}^{* *}-0.0027 \mathrm{x}^{2 * *}$ & $\mathrm{R}^{2}=0.63$ & 25 \\
K & $\hat{Y}=6.8908+1.6929 \mathrm{x}^{* *}-0.0304 \mathrm{x}^{2 * *}$ & $\mathrm{R}^{2}=0.97$ & 28 \\
Ca & $\hat{Y}=5.2022+0.5355 \mathrm{x}^{* *}-0.0106 \mathrm{x}^{2 * *}$ & $\mathrm{R}^{2}=0.87$ & 25 \\
Mg & $\hat{Y}=\bar{Y}=5.79$ & - & 20 \\
S & $\widehat{Y}=\bar{Y}=1.50$ & - & 20
\end{tabular}

Note. RD: recommended dose in $\mathrm{mg} \mathrm{dm}^{-3}$; LP: length of the pod, in $\mathrm{cm}$; WP: pod weight, in $\mathrm{g}_{\text {plant }}{ }^{-1}$; NPP: number of pod per plant; NGP: number of grains per pod; NTG: total number of grains per plant; WTG: total weight of grains per plant, in $\mathrm{g} \mathrm{plant}^{-1}$; and leaf contents of $\mathrm{N}, \mathrm{P}, \mathrm{K}, \mathrm{Ca}, \mathrm{Mg}$ and $\mathrm{S}$, in $\mathrm{g} \mathrm{kg}^{-1}$ * $^{*}$ and ${ }^{* *}$ significant at 5 and $1 \%$ probability, respectively, by the $\mathrm{F}$ test.

The response of lima bean to sulfate fertilization is related to the low availability of this element in the soil under study, reflecting its low organic matter and clay content. The ability of the soil to meet crop demand for this nutrient is directly related to the organic matter content of the soil and the mineralization of organic sulfur to inorganic forms (Tiecher et al., 2013).

The average values for $\mathrm{P}$ and $\mathrm{Ca}$ contents in the shoot were 5.25 and $11.96 \mathrm{~g} \mathrm{~kg}^{-1}$ at the dose of $25 \mathrm{mg} \mathrm{S} \mathrm{dm}^{-3}$, respectively. While for $\mathrm{K}$ the maximum concentration was $30.45 \mathrm{~g} \mathrm{~kg}^{-1}$ at the dose of $28 \mathrm{mg} \mathrm{S} \mathrm{dm}^{-3}$.

\section{Conclusions}

The addition of macronutrients promotes increments on the yield components and nutritional status of lima bean grown in Entisol Quartzipsamment.

The doses of macronutrients that promote higher productive yield and adequately supply the nutritional needs of lima bean are: $25 \mathrm{mg} \mathrm{N} \mathrm{dm}^{-3} ; 157 \mathrm{mg} \mathrm{P}_{2} \mathrm{O}_{5} \mathrm{dm}^{-3} ; 90 \mathrm{mg} \mathrm{K}_{2} \mathrm{O} \mathrm{dm}^{-3} ; 1.27 \mathrm{cmol}_{\mathrm{c}} \mathrm{Ca} \mathrm{dm}^{-3} ; 0.50 \mathrm{cmol}_{\mathrm{c}} \mathrm{Mg} \mathrm{dm}^{-3}$ and 30 $\mathrm{mg} \mathrm{S} \mathrm{dm}{ }^{-3}$.

\section{Acknowledgements}

We gratefully acknowledge the Conselho Nacional de Desenvolvimento Científico e Tecnológico (CNPq) and Coordenação de Aperfeiçoamento de Pessoal de Nível Superior (CAPES) for financial support and scholarships.

\section{References}

Alovisi, A. M. T., Furtini Neto, A. E., Carneiro, L. F., Curi, N., \& Alovisi, A. A. (2014). Silicon-phosphorus interactions in soils cultivated with bean plants. Acta Scientiarum Agronomy, 36(1), 79-86. https://doi.org/ 10.4025/actasciagron.v36i1.17240

Alves, A. U., Oliveira, A. P., Alves, A. U., Dornelas, C. S. M., Alves, E. U., Cardoso, E. A., ... Cruz, I. S. (2008). Lima beans production and economic revenue as function of organic and mineral fertilization. Horticultura Brasileira, 26(2), 251-254. https://doi.org/10.1590/S0102-05362008000200024

Barbosa, L. P., Costa, P. F., Ribeiro, P. R. A., Rufini, M., Guimarães, A. A., \& Moreira, F. M. S. (2017). Symbiotic efficiency and genotypic characterization of variants of Bradyrhizobium spp. in commercial inoculants for soybeans. Revista Brasileira de Ciência do Solo, 41. https://doi.org/10.1590/ 18069657 rbcs20160572

Bevilaqua, G. A. P., Silva Filho, P. M., \& Possent, J. C. (2002). Aplicação foliar de cálcio e boro e componentes de rendimento e qualidade de sementes de soja. Ciência Rural, 32(1), 31-34. https://doi.org/10.1590/S010384782002000100006

Bitocchi, E.; Rau, D.; Bellucci, E.; Rodriguez, M.; Murgia, M. L.; Santo, D., ... Papa, R. (2017). Beans (Phaseolus ssp.) as a model for understanding crop evolution. Frontiers in Plant Science, 8(722), 1-21. 
https://doi.org/10.3389/fpls.2017.00722

Canizella, B. T., Moreira, A., Moraes, L. A. C., \& Fageria, N. K. (2016). Water-soluble cations in shoot dry weight of common bean and balance of ions in the soil in response to the magnesium application. Journal Plant Nutrution, 39, 1713-1723. https://doi.org/10.1080/01904167.2016.1161792

CFEMG (Comissão de Fertilidade de Solos do Estado de Minas Gerais). (1999). Recomendações para o uso de corretivos e fertilizantes em Minas Gerais ( $5^{\mathrm{a}}$ aproximação). Viçosa, Brazil.

Chen, Z. C., Peng, W. T., Li, J., \& Liao, H. (2018). Functional dissection and transport mechanism of magnesium in plants. Seminars in Cell and Developmental Biology, 74, 142-152. https://doi.org/10.1016/j.semcdb.2017. 08.005

Crusciol, C. A. C., Soratto, R. P., Silva, L. M., \& Lemos, L. B. (2006). Aplicação de enxofre em cobertura no feijoeiro em sistema de plantio direto. Bragantia, 65(3), 459-465. https://doi.org/10.1590/S0006-87052006 000300012

Embrapa (Empresa Brasileira de Pesquisa Agropecuária). (2009). Manual de análises químicas de solos, plantas e fertilizantes (2nd ed.). Brasília: Embrapa Informação Tecnológica.

Embrapa (Empresa Brasileira de Pesquisa Agropecuária). (2013). Sistema Brasileiro de Classificação de Solos (3rd ed.). Brasília: Embrapa Informação Tecnológica.

Fageria, N. K., \& Melo, L. C. (2014). Agronomic evaluation of dry bean genotypes for potassium use efficiency. Journal Plant Nutrition, 37, 1899-1912. https://doi.org/10.1080/01904167.2014.911889

Fageria, N. K., \& Santos, A. B. (2008). Yield physiology of dry bean. Journal of Plant Nutrition, 31, 983-1004. https://doi.org/10.1080/01904160802096815

Guimarães, W. N. R., Martins, L. S. S., Silva, E. F., Ferraz, G. M. G., \& Oliveira, F. J. (2007). Caracterização morfológica e molecular de acessos de feijão-fava (Phaseolus lunatus L.). Revista Brasileira de Engenharia Agricola e Ambiental, 11(1), 37-45. https://doi.org/10.1590/S1415-43662007000100005

IBGE (Instituto Brasileiro de Geografia e Estatística). (2014). Produção agrícola municipal-culturas temporárias e permanentes. Instituto Brasileiro de Geografia e Estatística, 41.

IBGE (Instituto Brasileiro de Geografia e Estatística). (2015). Produção agrícola municipal-culturas temporárias e permanentes. Instituto Braileiro de Geogrofia e Estatística, 42.

Jost, E., Ribeiro, N. D., Maziero, S. M., Cerutti, T., \& Rosa, D. P. (2009). Efeitos gênicos do teor de cálcio em grãos de feijão. Ciência Rural, 39(1), 31-37. https://doi.org/10.1590/S0103-84782008005000055

Lacerda, R. R., Nascimento, E. S., Lacerda, J. T. J. G., Pinto, L. S., Rizzi, C., Bezerra, M. M., ... Gadelha, T. S. (2017). Lectin from seeds of a Brazilian lima bean variety (Phaseolus lunatus L. var. cascavel) presents antioxidant, antitumour and gastroprotective activities. International Journal of Biological Macromolecules, 95, 1072-1081. https://doi.org/10.1016/j.ijbiomac.2016.10.097

Lin, D. C., \& Nobel, P. S. (1971). Control of photosynthesis by $\mathrm{Mg}^{2+}$. Biochemistry and Biophysics, 145, 622-632. https://doi.org/10.1016/S0003-9861(71)80022-X

Malavolta, E. (2006). Manual de nutrição mineral de plantas. São Paulo: Ceres.

Marschner, H. (2012). Mineral nutrition of higher plants (3rd ed.). London: Elsevier. https://doi.org/10.1016/ B978-0-12-384905-2.00015-7

Oliveira, A. P., Alves, E. U., Alves, A. U., Dornelas, C. S. M., Silva, J. A., Pôrto, M. L., \& Alves, A. V. (2004). Produção de feijão-fava em função do uso de doses de fósforo. Horticultura Brasileira, 22(3), 543-546. https://doi.org/10.1590/S0102-05362004000300008

Oliveira, F. N., Torres, S. B., \& Bebedito, C. P. (2011). Caracterização botânica e agronômica de acessos de feijãofava, em mossoró, RN. Revista Caatinga, 24(1), 143-148;

R Development Core Team. (2012). R: A language and environment for statistical computing. Vienna, Austria: R Foundation for Statistical Computing. Retrieved from http://www.r-project.org

Salinas, R., Sánchez, E., Ruíz, J. M., Lao, M. T., \& Romero, L. (2014). Phosphorus levels influence plasma membrane $\mathrm{H}+$-ATPase activity and $\mathrm{K}^{+}, \mathrm{Ca}^{2+}$, and $\mathrm{Mg}^{2+}$ assimilation in green bean. Soil Science and Plant Analyse, 44(1), 456-464. https://doi.org/10.1080/00103624.2013.744127

Sandim, A. S., Bull, L. T., Furim, A. R., Lima, G. S., \& Garcia, J. L. N. (2014). Phosphorus availability in oxidic 
soils treated with lime and silicate applications. Revista Brasileira Ciência do Solo, 38(1), 1215-1222. https://doi.org/10.1590/S0100-06832014000400018

Santiago, F. E. M., Nóbrega, J. C. A., Santiago, F. L. A., Edvan, R. L., Nóbrega, R. S. A., \& Moreira, F. M. S. (2017). Lime and phosphate application as mycorrhizae stimulation to enhance growth and yield of Marandu grass. Semina: Ciência Agrária, 38(4), 2323-36. https://doi.org/10.5433/1679-0359.2017v38n4 Supl1p2323

Santos, D., Corlett, F. M. F., Mendes, J. E. M. F., \& Wanderley, J. S. A. (2002). Produtividade e morfologia de vagens e sementes de variedades de fava no Estado da Paraíba. Pesquisa Agropecuária Brasileira, 37(10), 1407-1412. https://doi.org/10.1590/S0100-204X2002001000008

Santos, H. C., Oliveira, F. H. T., Souza, A. P., Salcedo, I. H., \& Silva, V. D. M. (2016). Phosphorus availability as a function of its time of contact with different soils. Revista Brasileira de Engenharia Agrícola e Ambiental, 20(11), 996-1001. https://doi.org/10.1590/1807-1929/agriambi.v20n11p996-1001

Santos, J. Z. L., Furtini Neto, A. E., Resende, Á. V., Carneiro, L. F., Curi, N., \& Moretti, B. S. (2011). Resposta do feijoeiro à adubação fosfatada em solos de cerrado com diferentes históricos de uso. Revista Brasileira de Ciência do Solo, 35(1), 193-202. https://doi.org/10.1590/S0100-06832011000100018

Silva, E. J. A. F., Messias, U., Teixeira, A., Gonçalves, J. G. R., Chiorato, A. F., \& Carbonell, S. A. M. (2014). Efficiency in the use of phosphorus by common bean genotypes. Scientia Agricola, 71(3), 232-239. https://doi.org/10.1590/S0103-90162014000300008

Soratto, R. P., \& Crusciol, C. A. C. (2007). Cátions hidrossolúveis na parte aérea de culturas anuais mediante aplicação de calcãrio e gesso em superfície. Revista Brasileira de Ciência do Solo, 31(4), 81-90. https://doi.org/10.1590/S0100-06832007000100009

Tiecher, T., Santos, D. R., Alvarez, J. W. R., Mallmann, F. J. K., Piccin, R., \& Brunetto, G. (2013). Respostas de culturas à adubação sulfatada e deposição de enxofre atmosférico. Revista Ceres, 60(3), 420-427. https://doi.org/10.1590/S0034-737X2013000300016

Turrent, F. A. (1979). Uso de una matriz mixta para la optimización de cinco a ocho factores controlables de la producción (Boletim Técnico, 6). Chapingo: Rama de Suelos.

Verbruggen, N., \& Hermans, C. (2013). Physiological and molecular responses to magnesium nutritional imbalance in plants. Plant Soil, 368(2), 87-99. https://doi.org/10.1007/s11104-013-1589-0

Véry, A. A., Nieves-Cordones, M., Daly, M, K. I., Fizames, C., \& Sentenac, H. (2014). Molecular biology of K ${ }^{+}$ transport across the plant cell membrane: What do we learn from comparison between plant species? Journal Plant Physiology, 171(3), 748-769. https://doi.org/10.1016/j.jplph.2014.01.011

Wang, Y., \& Wu, W. H. (2017). Regulation of potassium transport and signaling in plants. Plant Biology, 39(4), 123-128. https://doi.org/10.1016/j.pbi.2017.06.006

Werle, R., Garcia, R. A., \& Rosolem, C. A. (2009). Lixiviação de potássio em função da textura e da disponibilidade do nutriente no solo. Revista Brasileira Ciência do Solo, 32(4), 2297-2305. https://doi.org/ $10.1590 / \mathrm{S} 0100-06832008000600009$

\section{Copyrights}

Copyright for this article is retained by the author(s), with first publication rights granted to the journal.

This is an open-access article distributed under the terms and conditions of the Creative Commons Attribution license (http://creativecommons.org/licenses/by/4.0/). 